\title{
PENGATURAN PERDAGANGAN JASA DALAM HUKUM EKONOMI INTERNASIONAL ${ }^{1}$
}

\author{
Oleh: Djoni Satriana \\ Devisi KPR Satwika Group, \\ Mahasiswa Magister Ilmu Hukum Universitas Pamulang \\ Email: djonikpr@yahoo.co.id
}

\begin{abstract}
Abstrak
Perdagangan internasional sebagai salah satu bagian dari kegiatan ekonomi atau kegiatan bisnis, dalam dekade terakhir ini menunjukkan perkembangan yang sangat pesat, ditengah semakin meningkatnya perhatian dunia usaha terhadap kegiatan bisnis internasional. Fenomena ini dapat dicermati dari semakin berkembangnya arus peredaran barang, jasa, modal dan tenaga kerja antarnegara, serta berkembangnya kegiatan bisnis melalui hubungan ekspor impor, investasi, perdagangan jasa, lisensi dan waralaba (license and franchise), hak atas kekayaan intelektual serta berbagai jenis perdagangan internasional lainnya.
\end{abstract}

Kata Kunci: Pengaturan Perdagangan Jasa, Hukum Ekonomi Internasional

\begin{abstract}
International trade as one part of economic activity or business activities, in the last decade shows very rapid development, amid increasing concern businesses to international business activities. This phenomenon can be observed from the growing flow of circulation of goods, services, capital and labor between countries, as well as the development of business activities through relations import-export, investment, trade in services, license and franchise (license and franchise), intellectual property rights as well as various types of trade other international.
\end{abstract}

Keywords: Setting for Trade in Services, International Economic Law

\section{A. Latar Belakang}

Perdagangan internasional sebagai salah satu bagian dari kegiatan ekonomi atau kegiatan bisnis, dalam dekade terakhir ini menunjukkan perkembangan yang sangat pesat, ditengah semakin meningkatnya perhatian dunia usaha terhadap kegiatan bisnis internasional. Fenomena ini dapat dicermati dari semakin berkembangnya arus peredaran barang, jasa, modal dan tenaga kerja antarnegara, serta berkembangnya kegiatan bisnis melalui hubungan ekspor impor, investasi, perdagangan jasa, lisensi dan waralaba (license and franchise), hak atas kekayaan intelektual serta berbagai jenis perdagangan internasional lainnya.

\footnotetext{
${ }^{1}$ Naskah diterima tanggal 14 April 2016, direvisi: 31 Mei 2016, disetujui untuk terbit 17 Juni 2016 dalam Volume 3 No. 1 Juli 2016
} 
Perdagangan internasional telah men "drive” perdagangan dalam negeri untuk bertransformasi menjadi perdagangan global, di mana seluruh dunia adalah pasar global, globalisasi berarti bahwa arus barang, jasa, modal, teknologi dan orang menyebar di seluruh dunia, Unsur inti dari globalisasi adalah ekspansi perdagangan dunia melalui penghapusan atau pengurangan hambatan perdagangan, seperti tarif impor.

Ekonomi "globalisasi" sebagai hasil dari perdagangan internasional adalah proses sejarah, hasil dari inovasi manusia dan kemajuan teknologi. Hal ini mengacu pada peningkatan integrasi ekonomi seluruh dunia, terutama melalui pergerakan barang, jasa, dan modal lintas batas. Istilah ini kadang-kadang juga mengacu pada pergerakan manusia (tenaga kerja) dan pengetahuan (teknologi) melintasi perbatasan internasional.

Ada berbagai alasan mengapa negara atau sebjek hukum (pelaku perdagangan) melakukan perdagangan internasional, diantaranya karena perdagangan internasional adalah tulang punggung bagi negara untuk menjadi makmur, sejahtera dan kuat. Hal ini sudah terbukti dalam perjalanan sejarah perkembangan dunia.

Liberalisasi perdagangan internasional mulai mengalami pertumbuhan yang sangat pesat pada abad ke-19 sehingga memberikan keuntungan dalam bidang ekonomi di Eropa. Tetapi kebebasan perdagangan tersebut belum dapat dinikmati oleh bangsa lainnya diluar Eropa, terutama di Asia dan Afrika. Hal ini disebabkan karena waktu itu Asia dan Afrika merupakan wilayah kolonial atau jajahan negara-negara Eropa, sehingga dalam sektor perdagangan, bangsa Asia dan Afrika tidak mendapatkan kesempatan dan kebebasan yang sama seperti bangsa Eropa.

Dengan demikian yang memegang kekuasaan ekonomi maupun politik pada periode liberal ini adalah bangsa Eropa, sebaliknya bangsa Asia dan Afrika tidak mempuanyai kekuasaan dan politik di negerinya sendiri.

Timbulnya kebebasan dalam melaksanakan perdagangan antar negara atau disebut dengan perdagangan internasional termotivasi oleh paham dan teori yang dikemukakan oleh Adam Smith dalam bukunya berjudul “The Wealth of Nation”, yang menyatakan bahwa kesejahteraan masyarakat suatu negara justru akan semakin meningkat, jika perdagangan internasional dilakukan dalam pasar bebas dan intervensi pemerintah dilakukan seminimal mungkin. 
Kebijakan dalam rangka liberalisasi dapat dikelompokkan menjadi dua yaitu yang dilakukan secara global dan unilateral, dan yang dilakukan secara bilateral atau regional. Kebijakan yang berlaku global berkaitan dengan kesepakatan yang diputuskan di WTO dan yang unilateral adalah kebijakan yang secara sepihak dilaksanakan oleh negara tersebut. Kebijakan regional atau bilateral adalah kebijakan yang dilaksanakan berdasarkan pada kesepakatan secara bilateral atau regional yang biasanya berada dalam suatu perjanjian perdagangan baik bilateral maupun regional.

Tahun 1995 menjadi sebuah babak baru dalam perekonomian internasional. Pada tahun ini, dibentuklah organisasi perdagangan yang lebih formal yakni World Trade Organization (WTO). Dibentuknya WTO ini sekaligus menggantikan rezim perdagangan lama yaitu General Agreements on Tariffs and Trade (GATT) yang telah berjalan sejak 1947. Perubahan rezim perdagangan ini tentu menimbulkan dampak terhadap perekonomian internasional secara umum. Sebagai sebuah organisasi, WTO lebih memiliki legalitas dan aturan yang lebih jelas serta mengikat. Berikut merupakan ulasan dari proses terbentuknya WTO dan keberadaannya sebagai organisasi perdagangan internasional.

Khusus di sektor Jasa, bidang ini memberi kontribusi besar terhadap pendapatan negara. Jasa telah memainkan peran yang semakin berpengaruh dalam perekonomian dan ketenagakerjaan suatu negara. Dalam bentuk yang ideal, liberalisasi perdagangan jasa adalah suatu keadaan dimana perusahaan dan individu bebas untuk menjual jasa melampaui batas wilayah negaranya. Ini berarti termasuk didalamnya adalah kebebasan untuk mendirikan perusahaan di negara lain dan bagi individu untuk bekerja di negara lain. Terlepas dari munculnya kekhawatiran akan munculnya "neo -liberalisme” dan neo-neo yang lainnya, liberalisasi perdagangan jasa muncul karena beberapa fakta. ${ }^{2}$

\section{B. Rumusan Masalah}

1. Apa perbedaan antara perdagangan jasa dan perdagangan barang?

2. Bagaiamana pengaturan perdagangan jasa dalam hukum ekonomi internasional?

\footnotetext{
${ }^{2}$ Basuki Antariksa, "Pengaruh Liberalisasi perdagangan Jasa Terhadap Daya Saing Kepariwisataan Indonesia”, Pusat Pendidikan dan Pelatihan Pegawai Kementrian Kebudayaan dan Pariwisata, Makalah, 29 Juli, 2010.
} 


\section{Tujuan penulisan}

1. Untuk mengetahui perbedaan antara perdagangan jasa dan perdagangan barang.

2. Untuk mengetahui pengaturan perdagangan jasa menurut hukum ekonomi internasional.

\section{Metode Penelitian}

\section{Pendekatan Penelitian}

Jenis penelitian ini yang dipergunakan dalam penelitian ini adalah metode hukum normatif. Penelitian hukum normatif atau yuridis normatif, yakni merupakan penelitian yang dilakukan dengan mengacu pada norma-norma hukum yang terdapat dalam peraturan perundang-undangan tertulis dan putusan-putusan pengadilan serta normanorma hukum yang ada pada masyarakat. ${ }^{3}$

\section{Sumber dan Jenis Data}

a. Data Primer.

Data primer yaitu data yang diperoleh langsung dari lapangan, yang berhubungan dengan perumusan masalah penelitian. Data-data ini diperoleh dengan melakukan wawancara dengan responden, Yaitu : Para pelaku bisnis yang berkaitan dengan hubungan permodalan Asing ( PMA )

\section{b. Data Sekunder}

Data sekunder yaitu data yang didapat melalui penelitian kepustakaan (Library Research) yang berhubungan dengan masalah hokum dagang internasional tentang perdagangan jasa terkait penyelesaian sengketa investasi modal asing.

Data Sekunder ini berupa :Bahan hukum primer, baha-bahan hukum yang mengikat, seperti perundang-undangan.Bahan hukum sekunder, terdiri dari buku-buku teori, hasil-hasil penelitian, dan pendapat para ahli yang berhubungan dengan penulisan.Bahan hukum tersier, dalam hal ini penulis menggunakan Kamus Besar Bahasa Indonesia (KBBI). ${ }^{4}$

\footnotetext{
${ }^{3}$ Soerjono Soekanto, Pengantar Penelitian Hukum, Jakarta; Universitas Indonesia Press, 2005, $\operatorname{hlm} 44$

${ }^{4}$ Amiruddin dan Zainal Asikin, Pengantar Metode Penelitian Hukum, Jakarta : PT.Raja Grafindo Persada, 2004.
} 
Nama lain dari penelitian yuridis normatif adalah penelitian hukum doctrinal, juga disebut sebagai penelitian kepustakaan atau studi dokumen. ${ }^{5}$ Penelitian ini membahas doktrin-doktrin atau asas-asas dalam ilmu hukum ${ }^{6}$ melalui kajian asas-asas hukum internasional, konvensi-konvensi, dan kerangka perjanjian internasional.

\section{E. Pembahasan}

\section{Perbedaan Pedagangan Jasa Dan Perdagangan Barang}

Perdagangan jasa memiliki karakteristik-karakteristik yang membedakannya dengan perdagangan barang. Pertama adalah nature of service transactions. ${ }^{7}$ Dalam sektor jasa, transaksi mengharuskan kehadiran kedua belah pihak, yaitu produsen dan konsumen. Jika produsen-produsen jasa disuatu negara memiliki sebuah produk jasa yang diminati oleh konsumen dari luar negeri, maka konsumen luar negeri tersebut harus langsung bertransaksi dengan produsen untuk mendapatkan produk jasa tersebut. Jadi penyediaan produk jasa terhadap pasar luar negeri seringkali disertai pergerakan modal atau tenaga kerja.

Karakteristik yang lain adalah regulasi dan kontrol yang besar pada perdagangan jasa. ${ }^{8}$ Regulasi dan kontrol yang besar ini dalam rangka, pertama, menghindari resiko terjadinya market failure atau kegagalan pasar dari kurangnya informasi atau lack of information yang didapat konsumen pada produk yang akan dikonsumsinya. Seperti yang kita ketahui bahwa pasar dapat menjadi alokasi sumber daya yang efisien (yaitu bertemunya permintaan konsumen dan penawaran produsen) jika asumsi-asumsinya terpenuhi, yang salah satunya adalah informasi yang sempurna. Jika tidak, maka pasar gagal menjadi alat alokasi sumber daya yang efisien. Konsumen tidak akan pernah tahu persis tentang kualitas produk yang akan dikonsumsinya. Oleh karena itu diperlukan informasi yang sempurna mengenai produk tersebut. Misal contoh yang terjadi pada perdagangan jasa, jika konsumen disuatu negara ingin menggunakan jasa tenaga ahli

\footnotetext{
${ }^{5}$ Bambang Soegono, Metode Penelitian Hukum, Jakarta; Raja Grafindo Persada, edisi 8,2006, hlm 42.

6 Zainuddin Ali, Metode Penelitian Hukum, (Jakarta; Sinar Grafika, 2010), hlm 24.

${ }^{7}$ Sherry Stephenson, et.al, Services Trade Liberalisation and Facilitation, dalam Safari Ar Rizqi. Penyebab Lambatnya Penetapan Mutual Recognition Arrangement Jasa ASEAN (1995-2005). Tesis. Fisip UI. 2010. hlm 5
} 
konstruksi asing, maka ia harus mengetahui kualitas dari tenaga ahli yang akan digunakannya tersebut. Dan alangkah lebih baik jika kualitas tenaga ahli yang akan masuk ke negaranya tersebut telah terstandarisasi sesuai dengan regulasi yang ada. Kedua, regulasi dan kontrol yang besar ini sebagai konsekuensi dari penyediaan produk jasa yang berbeda dengan penyediaan produk barang. Jika di proses penyediaan produk barang mengenal istilah penyimpanan atau stock, maka dalam penyediaan produk jasa ini tidak dikenal istilah tersebut. Maksudnya, produk jasa disediakan secara langsung oleh produsennya tanpa melalui proses penyimpanan seperti pada produk barang. Jadi dapat disimpulkan bahwa regulasi dan kontrol yang besar pada perdagangan jasa ini ditujukan agar kedua belah pihak konsumen dan produsen tidak merasa dirugikan.

Selain itu yang membedakan perdagangan jasa dengan perdagangan barang adalah kesulitan untuk mendeteksi hambatan-hambatan yang ada didalamnya. ${ }^{9}$ Lebih sulit untuk mendeteksi hambatan-hambatan yang berada didalam perdagangan jasa daripada yang ada pada perdagangan barang. Hambatan-hambatan pada perdagangan barang dapat dideteksi dengan jelas melalui perbedaan harga atau price differential yang ada.

Sedangkan pada perdagangan jasa hambatan-hambatan agak sulit untuk dideteksi karena berupa peraturan-peraturan. Hambatan-hambatan perdagangan jasa ini less transparent dibandingkan dengan hambatan-hambatan perdagangan barang, ini yang menyebabkan sulit untuk mengetahui dampak hambatan tersebut. Sebagai tambahan, Mary E. Footer dalam tulisannya Global and Regional Approaches to The Regulation of Trade in Services juga menjelaskan karakteristik-karakteristik yang membedakan perdagangan jasa dengan perdagangan barang. Pertama, jasa itu bersifat intangible atau tidak nyata, tidak seperti barang yang bersifat tangible atau nyata, yang mana berisi hak dan kewajiban.

Contohnya hak dan kewajiban yang tidak terlihat itu tercermin pada international banking. Misal, claim \& liabilities warga negara suatu negara dalam bentuk mata uang asing atau claim \& liabilities warga asing dalam bentuk mata uang negara tersebut. Selain itu perdagangan jasa ini lebih terikat terhadap regulasi-regulasi

\footnotetext{
${ }^{9}$ Ibid. hlm 6
} 
dibandingkan perdagangan barang. Contoh, safety standard dalam industri penerbangan.

Penerapan perdagangan jasa seringkali berbenturan dengan hal-hal yang bersifat non-ekonomi. Misalnya, transborder broadcasting seringkali berbenturan dengan kebijakan kebudayaan nasional suatu negara. Struktur pasar sektor jasa juga dikarakteristikkan dengan adanya kompetisi yang tidak sempurna. Industri telekomunikasi merupakan contoh yang cukup baik dari imperfect competition ini. Di banyak negara, peralatanperalatan telekomunikasi disupply oleh pemerintah dan sistemnya pun dioperasikan secara monopoli oleh pemerintah.

\section{Pengaturan Perdagangan jasa menurut Hukum Ekonomi Internasional.}

Sebagai langkah untuk menangani masalah perdagangan internasional, pada bulan februari 1946, ECOSOC, suatu badan dibawah PBB, pada sidang pertamanya telah mengambil resolusi untuk mengadakan konfrensi guna menyusun piagam internasional dibidang perdagangan. Pada waktu yang hampir bersamaan, pemerintah AS mengeluarkan suatu draft atau konsep mengenai piagam untuk Internasional Trade Organization ( yang selanjutnya disingkat ITO). ${ }^{10}$

Pada tahun 1947, para perunding di Jenewa melaksanakan persiapan untuk merumuskan piagam ITO yang kemudian diserahkan kepada delegasi negara-negara peserta pada konfrensi Havana 1948. Disamping mempersiapkan teks piagam ITO (International Trade Organization), para perunding di Jenewa juga melakukan perundingan untuk menurunkan bea masuk atau tarif yang kemudian menjadi annex dalam perjanjian GATT dan secara formal merupakan bagian integral dari perjanjian GATT. Dapat ditambahkan bahwa hal ini berlaku untuk seterusnya dalam GATT bahwa setiap rangkaian perundingan di bidang tarif makan hasilnya menjadi bagian integral dari perjanjian GATT.

Secara struktur GATT diciptakan sebagai suatu perjanjian multilateral dan bukan suatu “organisasi”. Dalam kata lain resminya GATT mempunyai status yang sama dengan berbagai perjanjian perdagangan bilateral sebelumnnya. Tetapi dilihat dari substansi, pada waktu perundingan diadakan untuk merumuskan perjanjian GATT,

${ }^{10}$ Syahmin A.K. 2006. Hukum Dagang Internasional (Dalam Kerangka Studi Analitis). PT. RajaGrafindo Persada. Jakarta. hlm 64 
substansi, prinsip, dan sistem yang terkandung dalam perjanjian dibayangkan supaya kemudian beroperasi dibawah payung ITO.

Pada tahun 1948, piagam teks ITO selesai dirumuskan. Tetapi ITO tidak dapat terwujud karena kongres AS tidak dapat menyetujuinya ketika presiden AS menyerahkan teks kepada kongres untuk memperoleh persetujuan. Setelah berulang kali diusahakan oleh pihak eksekutif AS, maka pada tahun 1951, pertanda semakin menunjukkan secara jelas bahwa kongres tidak akan menyetujuinya. Dengan demikian maka presiden AS Harry Truman menarik kembali usulan ratifikasi piagam Havana.

Dengan tidak berhasilnya masyarakat internasional dalam mewujudkan ITO, maka GATT menjadi satu satunya instrument hukum yang menjadi lembaga utama dalam perdagangan internasional. Namun kemudian yang menjadi pertanyaan adalah bagaimana kemudian GATT menjadi sebuah lembaga utama dalam perdagangan, sedangkan ia belum pernah secara sah diwujudkan sebagai organisasi internasional dan sebelumnya dirancang sebagai perjanjian interim?

Menurut H.S Kartadjoemena, bahwa jawaban terhadap pertanyaan itu adalah penempuhan jalan yuridis fiktif dengan adanya protocol of provisional application yang secara teknis dapat segera menerapkan perjanjian GATT secara provisional dan darurat. Dalam mekanisme penerapan ketentuan yuridis ini, dapat dikemukakan bahwa GATT, sebagai suatu perjanjian, telah selesai perumusannya pada tahun 1947, sebelum perjanjian ITO yang di rencanakan sebagai payung dapat terwujud.

Pada waktu itu, terdapat perbedaan pandangan mengenai ratifikasi GATT dengan ITO sebagai payungnya di satu pihak dan urgensi untuk menerapkan dan meresmikan perjanjian bila telah selesai. Maka di terapkanlah Protocol of provisional application (PPA) bagi negara yang memerlukan GATT segera untuk disetujui dan bagi negara yang ingin meratifikasi GATT dan ITO secara bersamaan dapat menunggu hingga kedua perjanjian tersebut rampung.

Dalam kenyataanya, ITO akhirnya tak pernah berlaku dan GATT berdiri secara independen hingga terbentuknya secara resmi World Trade Organisation (WTO) pada 15 April 1994 sejalan dengan keberhasilan Uruguay round, sebagai pengganti ITO dan menjadi payung baru bagi GATT.

Perjalanan WTO hingga terbentuk, tidak terlepas dari pertemuan contracting parties GATT tingkat menteri yang diikuti oleh 108 negara, yang pertama kali 
dilaksanakan tanggal 20 september 1986 di Punta Del Este, Uruguay untuk meluncurkan perundingan perdagangan multilateral. Perundingan tersebut dilaksanakan selama 7 tahun, beberapa kali hingga selesai 15 April 1994 di Marakesh, Maroko yang kemudian melahirkan World Trade Organisation (WTO) yang memberikan pengaturan lebih lengkap dan konprehensip dibidang perdagangan. Rangkaian perundingan ini kemudian biasa dikenal dengan nama perundingan Uruguay round.

Perundingan tersebut tidak hanya membahas mengenai hal-hal klasik seperti “market acces”, tetapi juga membicarakan mengenai hal-hal baru yang tumbuh dan berkembang sehubungan dengan semakin majunya perdagangan dan ekonomi yang tumbuh semakin pesat, seperti bidang investasi dan juga Jasa yang yang tidak tersentuh dalam pengaturan GATT.

Salah satu hasil penting yang dihasilkan oleh Uruguay round adalah kesepakatan tentang kerangka kerja dibidang jasa atau yang biasa disebut GATS (General Agreement on Trade in Services), ini merupakan suatu perjanjian yang relatif baru dan juga merupakan perjanjian perdagangan multilateral yang pertama di bidang jasa. ${ }^{11}$

GATS merupakan hasil suatu proses panjang yang dimulai dengan inisiatif Amerika Serikat saat Tokyo Round. Saat itu Amerika Serikat mulai berusaha meyakinkan para peserta untuk mendukung prakarsanya memasukkan Trade in Services dalam GATT. Usaha ini berhasil pada tahun 1986 ketika diambil suatu keputusan yang tegas saat Deklarasi Punta Del Este tahun 1986.

Deklarasi Punta Del Este pada tahun 1986 merupakan suatu hasil kompromi antara negara maju dan negara berkembang mengenai perdagangan jasa. Kompromi ini muncul sebagai reaksi dari negara berkembang yang semula menentang dimasukkannnya pengaturan mengenai jasa dalam kerangka GATT. ${ }^{12}$ Hal ini tampak

11 Direktorat Perdagangan dan Perindustrian Multilateral Ditjen Multilateral Ekonomi, Keuangan dan Pembangunan Departemen Luar Negeri RI, Buku Seri Terjemahan PersetujuanPersetujuan WTO: Persetujuan Bidang Jasa (General Agreement on Trade in Services/ GATS), hlm. 1.

12 Mochtar Kusumaatmadja. Perjanjian WTO Mengenai Perdagangan Internasional Jasa (GATS) Dilihat dari Prespektif Negara Berkembang, Seminar Aspek Hukum Perdagangan Jasa Menurut WTO dan Komitmen Indonesia di Bidang Finansial, Institut Bankir Indonesia, 6 Maret 1997. Dalam Naufi Ahmad Naufal. Liberalisasi Jasa Konstrukasi Di Indonesia dan Kesesuaian dengan Komitmen dalam General Agreement On Trade In Services (GATS-WTO) di Bidang Jasa Konstrukasi. Tesis FH UI. 2008. Hlm 13. 
dalam keputusan Deklarasi Punta Del Este yang mengatur tentang perdagangan jasa yang intinya memuat pokok-pokok sebagai berikut:

1) Para menteri sepakat untuk meluncurkan perundingan perdagangan jasa sebagai bagian perundingan perdagangan multilateral.

2) Perundingan tersebut bertujuan membentuk kerangka hukum multilateral yang memuat prinsip dan ketentuan mengenai perdagangan jasa, sehingga tercipta perdagangan yang transparan dan liberalisasi progresif, sebagai upaya peningkatan ekonomi semua mitra dagang dan kemajuan negara-negara berkembang.

3) Kerangka hukum tersebut harus menghormati hukum nasional dan ketentuanketentuan yang berlaku mengenai jasa serta bekerja sama dengan organisasi internasional yang relevan.

4) Untuk melaksanakan perundingan ini harus dibentuk kelompok perundingan jasa yang berkewajiban untuk melaporkan hasilnya kepada Komite Perundingan Perdagangan.

Kompromi ini muncul sebagai reaksi dari negara berkembang yang semula menentang dimasukkannya pengaturan mengenai perdagangan jasa dalam kerangka GATT/WTO. Dalam perundingan ini negara berkembang berhasil menempatkannya dalam peraturan tersendiri di luar kerangka hukum dari GATT/WTO. Hal ini dilakukan untuk menghilangkan kemungkinan persilangan antara masalah-masalah GATT/WTO mengenai perdagangan barang dan perdagangan jasa. Negara berkembang juga berhasil dalam usaha agar perkembangan ekonomi dan pertumbuhan dimasukkan sebagai tujuan dari setiap persetujuan yang dicapai. Kerangka hukum tersebut melahirkan GATS. Pengaturan GATS dipandang sebagai suatu cara memajukan pertumbuhan ekonomi bagi semua negara pelaku perdagangan dan pembangunan negara-negara berkembang. Dimasukkannya pengaturan mengenai perdagangan jasa dalam kerangka GATT/WTO dianggap sebagai suatu langkah kemajuan penting bagi GATT/WTO. ${ }^{13}$

Dibentuknya GATS seperti ditegaskan dalam Deklarasi Punta Del Este adalah untuk membentuk suatu kerangka prinsip-prinsip atau aturan-aturan material mengenai perdagangan jasa. Dokumen-dokumen penting yang harus diperhatikan dalam 
mempelajari GATS adalah; framework agreement, initial commitments, sectoral annex dan ministerial decision and understanding. Framework agreement adalah perjanjian GATS itu sendiri yang mengandung satu perangkat konsep umum, asas, dan ketentuan yang menimbulkan kewajiban berkenaan dengan segala tindakan yang berkaitan dengan perdagangan jasa.

GATS adalah framework agreement yang tercantum di dalamnya prinsip-prinsip dasar yang merupakan landasan aturan permainan dalam perdagangan internasional di bidang jasa-jasa. Tujuannya adalah memperdalam dan memperluas tingkat libralisasi sektor jasa di negara-negara anggota, sehingga diharapkan perdagangan jasa di dunia bisa meningkat. ${ }^{14}$

Peranan GATS dalam perdagangan jasa dunia, pada dasarnya tidak terlepas dari dua (2) pilar berikut; pertama adalah memastikan adanya peningkatan transparansi dan prediktabilitas dari aturan maupun regulasi yang terkait, kedua adalah upaya mempromosikan proses liberalisasi berkelanjutan melalui putaran perundingan. ${ }^{15}$

Kewajiban-kewajiban bagi pihak dalam GATS dapat dibagi menjadi dua kelompok yaitu:

1. Kewajiban umum dan disiplin (general obligation and disciplines) adalah kewajiban yang diterapkan terhadap semua sektor jasa oleh semua negara anggota sesuai dengan sectoral annex (lampiran) yang ada. Kewajiban ini termasuk perlakuan Most Favoured Nation (MFN), ketentuan transparansi, ketersediaan prosedur hukum, konsultasi terhadap praktek-praktek bisnis, dan konsultasi terhadap subsidi yang mempengaruhi perdagangan.

2. Kewajiban khusus yaitu kewajiban-kewajiban dalam kaitannya dengan komitmen khusus (obligation related to specific commitment). Yang dimaksud dengan kewajiban khusus adalah kewajiban yang mengikat negara tertentu sesuai dengan komitmen yang dibuat sebagaimana tercantum dalam Schedule of Commitments (SoC). Hal-hal yang termasuk dalam kategori kewajiban khusus ini antara lain; prinsip-prinsip perlakuan nasional (Nationat Treatment) dan akses pasar (Market Acces).

${ }^{14}$ Ibid. hlm 15

${ }^{15}$ Direktorat Perdagangan dan Perindustrian Multilateral Ditjen Multilateral Ekonomi, Keuangan dan Pembangunan Departemen Luar Negeri RI. Op.cit. hlm 3 
Berdasarkan kewajiban khusus, maka setiap negara anggota harus memperlakukan jasa dan pemasok jasa dari negara lain sekurang-kurangnya sama dengan yang telah disetujui dan dicatat dalam Schedule of Commitments (SoC). Di samping itu setiap negara anggota juga harus memberikan perlakuan yang adil kepada jasa dan pemasok jasa dari anggota lain dibandingkan dengan yang diberikannya kepada jasa dan pemasok jasa sejenis miliknya (domestik).

GATS memuat 3 (tiga) dokumen antara lain sebagai berikut:

1. Dokumen yang memuat serangkaian kewajiban dasar yang berlaku terhadap semua negara.

2. Dokumen yang berisi beberapa lampiran (annex) perjanjian yang menetapkan keadaan-keadaan khusus mengenai sektor-sektor jasa pada setiap negara anggota WTO.

3. Dokumen yang memuat komitmen negara-negara yang tertuang dalam daftar yang berisi kewajiban negara (national schedule) untuk memperlancar proses liberalisasi perdagangan jasa.

Dokumen pertama yang merupakan satu framework agreement yang terdiri dari 39 Pasal dan terbagai atas 6 bagian. Bagian-bagian tersebut antara lain sebagai berikut:

1. Bagian I mengandung kewajiban-kewajiban dasar (basic obligation) berkenaan dengan definisi dan ruang lingkup jasa.

2. Bagian II mengandung ketentuan-ketentuan dengan kewajiban umum seperti Most Favoured Nation (MFN) atau non diskriminasi, transparency, ketentuan untuk peningkatan partisipasi negara-negara berkembang, kewajiban berkenaan dengan syaratsyarat pengakuan dalam bidang jasa, penggunaan pembatasan dalam transfer, dan pembayaran internasional.

3. Bagian III adalah bagian operatif yang mengandung ketentuan-ketentuan penting: market access, national treatment dan additional commitments. Ketentuan ini tidak dicantumkan sebagai general obligation, tetapi sebagai specific commitment yang harus dimuat dalam daftar komitmen nasional (national schedule).

4. Bagian IV adalah bagian yang meletakkan dasar bagi liberalisasi progresif jasa melalui peraturan perundingan perdagangan jasa. Termasuk penarikan kembali dan modifikasi komitmen dalam daftar komitmen nasional setelah 3 tahun. 
5. Bagian V mencakup ketentuan-ketentuan kelembagaan termasuk pembentukan Council on Trade in Services bersama dengan pasal-pasal mengenai konsultasi dan prosedur penyelesaian sengketa.

6. Bagian VI memuat ketentuan-ketentuan akhir (final provision)

Dokumen kedua mengatur ketentuan-ketentuan mengenai akses pasar dan perlakuan nasional dan bukan merupakan kewajiban umum. Tetapi merupakan komitmen yang ditetapkan dalam daftar nasional (Schedule of Commitments). Schedule of Commitments (SoC) ini memuat komitmen mengikat negara-negara anggota WTO terhadap anggota lainnya dalam melaksanakan kewajiban-kewajibannya berdasarkan GATS, dengan kata lain daftar tersebut merupakan konkretisasi dalam bentuk nyata dari komitmen negara anggota GATS-WTO.

Dokumen ketiga berkenaan dengan sektot-sektor khusus. Annex pertama adalah annex mengenai pengecualian terhadap Pasal II (perihal berlakunya MFN). Annex kedua mengenai pergerakan manusia (movement of natural persons) yang memberikan jasa di bawah GATS. kemudian ada pula beberapa annex yang bertalian dengan sektorsektor tertentu seperti: annex on air transport services, annex on financial services, second annex on financial services, annex on negotiation maritime transport services, annex on telecommunication, annex on negotiations on basic telecommunications.

Ruang lingkup jenis perdagangan jasa GATS terdapat dalam pasal 1 ayat (1) GATS yang berbunyi : " This Agreement applies to measures by member affecting trade in service”. Pasal ini mencoba memberikan penjelasan bahwa yang dimaksud dengan Trade in Service adalah perdagangan jasa yang dilakukan dengan cara. ${ }^{16}$

a. Jasa yang diberikan dari suatu wilayah negara lainnya (cross-border) misalnya jasa yang mempergunakan media telekomunikasi;

b. Jasa yang diberikan dalam suatu wilayah negara kepada suatu konsumen dari negara lain (consumption abroad) misalnya turisme;

c. Jasa yang diberikan melalui kehadiran badan usaha suatu negara dalam wilayah negara lain (commercial presence) misalnya pembukaan kantor cabang bank asing;

d. Jasa yang diberikan oleh warga negara suatu negara dalam wilayah negara lain (presence of natural person) misalnya jasa konsultan, pengacara dan akuntan.

\footnotetext{
${ }^{16}$ Syahmin AK, Op.cit, hlm 170-180
} 
Dengan demikian, tampak bahwa cakupan perdagangan jasa yang diatur oleh GATS ini relatif luas dan universal seperti halnya pengaturan dibidang Trade in Goods. Oleh karena itu beberapa asas-asas yang ada dalam GATT juga diterapkan dalam koteks perdagangan Jasa-jasa yang tercantum dalam GATS. Semisal prinsip MFN, liberalisasi secara bertahap dsb.

\section{Liberalisasi perdagangan jasa muncul karena beberapa fakta :}

Pertama : Perang Dunia I dan II terjadi akibat perang dagang antar negara. Perang dagang itu sendiri terjadi karena dianutnya doktrin merkantilisme yang mengajarkan bahwa kemajuan sebuah negara akan terjadi jika mampu meningkatkan ekspor semaksimal mungkin dan menekan impor seminimal mungkin. Doktrin ini mendorong negara-negara untuk menerapkan kebijakan perdagangan yang bersifat protektif. Kedua : Paham kapitalisme yang mendorong penumpukan kekayaan sebanyak-banyaknya. Paham ini melahirkan perusahaan multinasional yang melakukan ekspansi usaha ke berbagai negara untuk meningkatkan keuntungan secara berkesinambungan. Lebih jauh lagi, fenomena ini kemudian melahirkan praktek Foreign Direct Investment (FDI). Ketiga : Negara sedang berkembang memiliki kebutuhan untuk melakukan hubungan perdagangan dengan negara lain, misalnya ekspor tenaga kerja ke luar negeri. Berkaitan dengan hal tersebut, maka negara sedang berkembang juga menghendaki agar negara mitra dagangnya menerapkan kebijakan liberalisasi perdagangan jasa.

Pertumbuhan kelas menengah serta permintaan internasional sangat penting untuk pesatnya perkembangan sektor jasa. Keduanya mendorong perluasan jasa modern, pariwisata, transportasi dan layanan bisnis.

\section{Beberapa Aturan-Aturan Pokok Dalam Liberalisasi Jasa Yang Tedapat Dalam Gats}

a) Most Favoured-Nation Treatment ( MFN ) ${ }^{17}$

Prinsip MFN merupakan sebuah asas bahwa bila ada kemudahan yang diberikan kepada suatu negara, maka kemudahan tersebut juga harus di berikan kepada negara

\footnotetext{
${ }^{17}$ Syahmin A, ibid.hlm 184-185
} 
lainnya. Ini juga merupakan prinsip utama dalam perdagangan barang yang ada dalam GATT yang juga di gunakan dalam perdagangan jasa (GATS). MFN atau dikenal juga dengan prinsip non diskriminasi merupakan suatu kewajiban umum (General obligation) dalam GATS. Kewajiban ini bersifat segera (immediately) dan otomatis (unconditionally).

Dalam pengaturan mengenai MFN pada pasal II paragraph 1 GATS dipergunakan Rumusan “ ...Each member shall accord immediately and unconditionally to service and service supplier of any other member, "treatment no less favourable" than it accord to like service and service supplier of any other country". Istilah "treatment no less favourable" juga digunakan dalam pasal XVI tentang market acces dan pasal XVII tentang national treatment.

Perbedaannya ialah dalam MFN treatment no less favourable yang dibandingkan adalah perlakuan yang diberikan terhadapa service supplier dari suatu negara dengan negara lainnya, sedangkan dalam national treatment yang dibandingkan adalah perlakuan yang diberikan terhadap domestic service supplier dengan foreign service supplier.

Sementara itu, dalam market acces pengertiannya adalah perlakuan yang diberikan terhadap foreign service supplier oleh suatu negara harus sesuai dengan persyaratan dan pembatasan yang tercantum dalam schedule of commitment (SOC) negara itu.

Meskipun demikian, sistem GATS memberikan kebebasan bagi anggotanya untuk menyimpang dari kewajiban MFN. Oleh karena itu, suatu anggota dapat saja memberikan perlakuan yang lebih baik atas suatu sektor jasa kepada suatu atau beberapa anggota dibanding dengan yang diberikan kepada anggota lain sepanjang anggota lain tersebut diperlakukan minimal sesuai dengan yang dicantumkan dalam SOC.

Akan tetapi, suatu negara tidak dibenarkan untuk memberikan perlakuan yang lebih sedikit dari yang dicantumkan dalam SOC kepada suatu atau beberapa anggota (misalnya berdasakan prinsip resiprositas). 


\section{b) Protecting Through Specific Commitments ${ }^{18}$}

Dalam hal proteksi, perdagangan jasa berbeda dengan barang. Dalam perdagangan jasa, proteksi dengan menggunakan pembatasan tarif tersebut tidak bisa dilaksanakan karena jasa-jasa itu sendiri, mengingat sifatnya yangh abstrak, masuk ke suatu wilayah tidak melalui pelabuhan (Customs) sehingga tidak dapat dihambat melalui tarif. Oleh karena itu, proteksi yang dapat dilakukan dalam perdagangan jasa adalah dalam bentuk SOC yang dibuat masing-masing negara sesua dengan keadaan negara tersebut yang kemudian dirundingkan dengan mitra dagangnya.

SOC pada hakikatnya mengandung suatu “reservation”, artinya negara yang membuat SOC tersebut tunduk pada ketentuan GATS dengan disertai kondisi, pembatasan dan persyaratan sebagaimana tercantum dalam komitmennya tersebut.

SOC ini diatur pada bagian III yang terpisah dari bagian II GATS yang merupakan general obliagation. Dengan demikian dapatlah dikatakan bahwa Schedule of Commitment bukan merupakan automatic obligation, tapi merupakan specific obligation. Artinya yang menjadi kewajiban adalah sesuai dengan yang tecantum dalam SOC negara yang bersangkutan.

Dalam bagian III GATS (specific commitments) dikenal tiga macam komitmen, yaitu: 1. Komitmen market acces. 2. Komitmen national treatment; dan 3. Additional commitments.

Tiga macam komitmen ini digabung jadi satu dalam SOC dari masing masing negara. SOC dari masing-masing negara sesuai dengan pasal XX paragraph 3 menjadi bagian yang tidak terpisahkan dari GATS.

Dengan demikian SOC tersebut mengikat bagi negara yang membuatnya. Dengan SOC ini, tercermin juga suatu prinsip, yaitu prinsip liberalisasi dalam perdagangan jasa dilakukan secara bertahap (progressive liberalization) sesuai dengan keadaan dan kemampuan negara masing-masing. Hal ini sejalan dengan ketentuan pasal XIX GATS.

\section{c) Transparansi ${ }^{19}$}

Prinsip Transparansi ini diatur dalam pasal III GATS yang mewajibkan semua anggota mempublikasikan semua peraturan perundangan, pedoman pelaksanaan, serta

\footnotetext{
${ }^{18}$ Ibid. hlm 186-188

${ }^{19}$ Ibid.hlm 191-192
} 
semua keputusan dan ketentuan yang berlaku secara secara umum yang dikeluarkan oleh pemerintah pusat maupun daerah yang mempunyai dampak pada pelaksanaan GATS.

Disamping itu, juga diwajibkan untuk memberitahukan Council For the Trade and Service (salah satu "badan” dalam WTO) atas setiap perubahan atau dikeluarkannya peraturan perundangan yang baru yang berdampak terhadap perdagangan jasa yang dicantumkan dalam SOC. Pemberitahuan ini minimal dilakukan sekali dalam setahun.

\section{d) Peningkatan partisipasi negara yang sedang berkembang (Developed Country) ${ }^{20}$}

Secara prinsip sistem WTO tidak membedakan antara negara maju dan negara berkembang. Namun demikian, dalam kondisi-kondisi tertentu kepada negara-negara berkembang diberikan perlakuan khusus. Hal ini dapat dilihat dari perlakuan khusus yang diberikan kepada negara sedang berkembang dalam penyampaian SOC. Penyampaian SOC ini merupakan salah satu syarat untuk dapat menjadi original member WTO (pasal 11 WTO).

Kepada negara sedang berkembang (least developing country), diberikan waktu sampai dengan April 1995, sedangkan untuk negara lainnya batas waktu penyerahan adalah 15 Desember 1993.

Disamping itu, kepada negara sedang berkembang juga diberi kemudahan dalam rangka meningkatkan partisipasinya melalui perundingan SOC yang menyangkut:

1. Peningkatan kapasitas jasa dalam negeri dan efesiensi serta daya saing sektor jasa dalam negeri antara lain melalui akses kepada teknologi secara komersial;

2. Perbaikan akses terhadap jaringan distribusi dan informasi; dan

3. Liberalisasi akses pasar untuk sektor-sektor dan cara pemasokan yang menjadi kepentingan bagi ekspor negara berkembang (pasal IV(1) GATS.

Kemudahan lainnya yang diberikan kepada negara yang sedang berkembang adalah dalam rangka negosiasi selanjutnya untuk mebuka pasar. Kepada mereka diberikan fleksibilitas yang cukup untuk untuk membuka sektor yang lebih sedikit, melakukan perluasan akses pasar secara bertahap sejalan dengan situasi pembangunannya (pasal XIX ayat 2 GATS).

\footnotetext{
${ }^{20}$ Ibid. hlm 193-194
} 
Selanjutnya, dalam rangka membantu negara sedang berkembang, negara maju diwajibkan untuk mendirikan “contact point” untuk membantu negara berkembang dalam mengakses informasi mengenai pasar masing-masing negara maju. Informasi tersebut meliputi :

1. Aspek komersial dan teknis dari pemasok jasa;

2. Pendaftaran, pengakuan dan cara memperoleh kualifikasi professional; dan

3. Tersedianya teknologi jasa (pasal IV (2) GATS.

\section{e) Integrasi Ekonomi ${ }^{21}$}

Kerja sama regional telah lama dipandang sebagai pengecualian dari klausula MFN dalam perjanjian perdagangan. Meskipun demikian,WTO secara prinsip tidak melarang anggotanya untuk bergabung dengan organisasi kerjasama ekonomi regional seperti NAFTA (Nort America Free Trade Agreement), atau mengadakan perjanjian liberalisasi perdagangan jasa antara dua atau lebih negara, asal saja memenuhi beberapa kriteria yang rinci dan kompleks sebagaimana diatur dalam pasal V GATS.

\section{f) Liberalisasi bertahap}

Liberalisasi bertahap tersebut dilakukan dengan mewajibkan semua angota WTO untuk melakukan putaran negosiasi yang berkesinambungan yang dimulai paling lambat lima tahun sejak berlakunya perjanjian WTO (sejak 1 januari 1995). Negosiasi tersebut harus dilakukan dengan mengurangi atau menghilangkan measures yang dapat berdampak buruk terhadap perdagangan Jasa. Meskipun demikian, proses liberalisasi harus dilakukan dengan tetap menghomati kepentingan nasional dan tingkat pembangunan masing-masing (Pasal XIX ayat(1) GATS). Ketentuan dalam pasal XIX dapat digunakan oleh negara maju untuk menekan negara berkembang untuk melakukan perundingan selanjutnya. $^{22}$

Dalam pada itu, komitmen yang telah diberikan dalam rangka perundingan putaran Uruguay, dan telah menjadi annex dari GATS, pada prinsipnya tidak boleh ditarik, diubah dan/atau dikurangi. Perbaikan hanya dimungkinkan apabila dilakukan dengan maksud untuk meningkatkan komitmen. Penarikan dan/atau perubahan

\footnotetext{
${ }^{21}$ Ibid. hlm 194-195

${ }^{22}$ Ibid. hlm 195
} 
komitmen yang diberikan hanya dapat dilakukan dengan pembayaran kompenisasi kepada anggota yang dirugikan (Pasal XXI GATS). ${ }^{23}$

\section{g) Keadaan darurat}

Escape Clauses merupakan ketentuan yang penting dalam semua perjanjian internasional, yang hanya diberlakukan dalam kondisi atau kesulitan yang tidak dapat diperkirakan sebelumnya

Secara umum, escape clause membolehkan suatu anggota dalam kondisi tertentu, untuk sementara menghindar dari satu aspek perjanjian tanpa merusak tujuan dari perjanjian tersebut secara keseluruhan. Escape Clause dalam suatu perjanjian memberikan kepastian bagi penandatangan bahwa dalam situasi darurat, mereka dibenarkan untuk sementara menghindar dari komitmen yang telah diberikan. ${ }^{24}$

Dalam GATS anggota dalam keadaan darurat juga dibenarkan untuk melakukan penyimpangan sementara dari komitmen yang diberikannya. Penyimpangan tersebut dapat dilakukan dalam hal kesulitan Negara pembayaran. Dalam kondisi seperti ini anggota diperkenankan melakukan pembatasan-pembatasan didalam perdagangan jasa yang telah dicantumkan dalam SOC-nya. Pembatasan tersebut dilakukan dengan syarat: 25[21]

1. Tidak menimbulkan diskriminasi diantara sesama anggota;

2. Konsisten dengan ketentuan-ketentuan International Monetery Fund (IMF)

3. Menghindarkan kerugian komersial, ekonomi dan keuangan anggota lainnya;

4. Tidak melebihi hal-hal yang perlu untuk mengatasi keadaan;

5. Harus bersifat sementara dan harus dihapuskan secara bertahap.

Tindakan pengamanan darurat, selain masalah kesulitan neraca pembayaran yang dapat dilakukan anggota, masih akan dirundingkan secara multilateral. Perundingan tersebut sudah harus dimulai paling lambat tiga tahun setelah berjalannya WTO. Hal ini untuk memberikan kesempatan bagi anggota untuk mempelajari kesulitan apa saja yang mungkin timbul setelah berjalannya GATS, mengingat perdagangan jasa belum diatur sebelumnya. ${ }^{26}$

\footnotetext{
${ }^{23}$ Ibid. hlm 196

${ }^{24}$ Ibid. hlm 197

${ }^{25}$ Ibid. hlm 197-198

${ }^{26}$ Ibid, hlm 198
} 
Penyelesaian sengketa investasi modal asing merupakan sebuah persoalan yang relatif ada bagi negara yang membuka diri terhadap investasi asing di negaranya. Negara-negara yang merasa bahwa eksistensi investasi akan memberikan implikasi yang besar bagi pemasukan negara, maka akan sedemikian rupa men-design sistem hukumnya agar mampu berkolaborasi dengan kepentingan investasi tanpa mengorbankan kepentingan bangsa dan negara. Indonesia sebagai negara yang juga membuka pintu investasi dalam upaya pemanfaatan pelauang investasi dan sebagai resiko bagian masyarakat internasional yang mau tidak mau harus membuka peluang investasi bagi pelaku usaha manapun dan darimanapun, juga telah meregulasi aturanaturan investasi, terbaru adalah Undang-undang tentang Penanaman Modal No.25 Tahun 2007, Undang-undang tentang Arbitrase dan Alternatif Penyelesaian Sengketa No. 30 tahun 1999, dan aturan hukum internasional yang diratifikasi terkait penyelesaian sengketa investasi dan perdagangan.

\section{F. Kesimpulan}

Perdagangan jasa menurut pasal 1 ayat (1) GATS yang berbunyi : “ This Agreement applies to measures by member affecting trade in service”. Pasal ini mencoba memberikan penjelasan bahwa yang dimaksud dengan Trade in Service adalah perdagangan jasa yang dilakukan dengan cara :

1) Jasa yang diberikan dari suatu wilayah negara lainnya (cross-border) misalnya jasa yang mempergunakan media telekomunikasi;

2) Jasa yang diberikan dalam suatu wilayah negara kepada suatu konsumen dari negara lain (consumption abroad) misalnya turisme;

3) Jasa yang diberikan melalui kehadiran badan usaha suatu negara dalam wilayah negara lain (commercial presence) misalnya pembukaan kantor cabang bank asing;

4) Jasa yang diberikan oleh warga negara suatu negara dalam wilayah negara lain (presence of natural person) misalnya jasa konsultan, pengacara dan akuntan.

Pengaturan mengenai Perdagangan jasa terdapat dalam General Agreement on Trade in Services (GATS) yang merupakan suatu perjanjian yang relatif baru dan juga merupakan perjanjian perdagangan multilateral yang pertama di bidang jasa. 


\section{G. Saran}

Perdagangan jasa memiliki karakteristik-karakteristik yang membedakannya dengan perdagangan barang. Pertama adalah nature of service transactions. Dalam sektor jasa, transaksi mengharuskan kehadiran kedua belah pihak, yaitu produsen dan konsumen. Kedua, regulasi dan kontrol yang besar pada perdagangan jasa. Regulasi dan kontrol yang besar ini dalam rangka, pertama, menghindari resiko terjadinya market failure atau kegagalan pasar dari kurangnya informasi atau lack of information yang didapat konsumen pada produk yang akan dikonsumsinya. Ketiga, kesulitan untuk mendeteksi hambatan-hambatan yang ada didalamnya. Lebih sulit untuk mendeteksi hambatan-hambatan yang berada didalam perdagangan jasa daripada yang ada pada perdagangan barang. Keempat, jasa itu bersifat intangible atau tidak nyata, tidak seperti barang yang bersifat tangible atau nyata, yang mana berisi hak dan kewajiban. 


\section{Daftar Pustaka}

\section{$\underline{\text { Buku }}$}

Basuki Antariksa, "Pengaruh Liberalisasi perdagangan Jasa Terhadap Daya Saing Kepariwisataan Indonesia”, Pusat Pendidikan dan Pelatihan Pegawai Kementrian Kebudayaan dan Pariwisata, Makalah, 29 Juli, 2010.

Bambang Soegono, Metode Penelitian Hukum, Jakarta; Raja Grafindo Persada, edisi 8, 2006.

Chairul Anwar, Hukum Perdagangan Internasional, Novindo Pustaka Mandiri, Jakarta 1999, Direktorat Perdagangan dan Perindustrian Multilateral Ditjen Multilateral Ekonomi, Keuangan dan Pembangunan Departemen Luar Negeri RI, Buku Seri Terjemahan Persetujuan-Persetujuan WTO: Persetujuan Bidang Jasa (General Agreement on Trade in Services/ GATS.

Huala Adolf, Arbitrase Komersial Internasional, Rajawali Press, Jakarta, 1991.

Komar Kantaatmadja, Beberapa Hal Tentang Arbitrase, FH-Unpad, Bandung, 1989.

Naufi Ahmad Naufal. Liberalisasi Jasa Konstrukasi Di Indonesia dan Kesesuaian dengan Komitmen dalam General Agreement On Trade In Services (GATSWTO) di Bidang Jasa Konstrukasi. Tesis FH UI. 2008.

Nurchalis. Analisis Hukum Internasional Terhadap Liberalisasi Perdagangan Dibidang Jasa Oleh Negara-Negara Asean Melalui Afas (Asean Framework Agreement On Service). Skripsi Fakultas Hukum Universitas Hasanudin Makassar. 2013.

Safari Ar Rizqi. Penyebab Lambatnya Penetapan Mutual Recognition Arrangement Jasa ASEAN (1995-2005). Tesis. Fisip UI. 2010.

Sudargo Gautama, Arbitrase Dagang Internasional, Alumni, Bandung, 1979

Soerjono Soekanto, Pengantar Penelitian Hukum, Jakarta; Universitas Indonesia Press, 2005.

Syahmin A.K. Hukum Dagang Internasional (Dalam Kerangka Studi Analitis). PT. RajaGrafindo Persada. Jakarta. 2006.

Zainuddin Ali, Metode Penelitian Hukum, Jakarta; Sinar Grafika, 2010.

\section{Referensi INTERNET}

Eddy Cahyono Sugiarto. WTO dan Peluang Indonesia. http://www.setkab.go.id/artikel9931-.html 